\title{
Aluminium and gallium trihalide adducts of 2,4,6-triorganylborazines and the synthesis of triorganylborazinium tetrabromoaluminates ${ }^{1}$
}

\author{
B. Gemünd ${ }^{a}$, B. Günther ${ }^{a}$, and H. Nöth ${ }^{b, *}$ \\ ${ }^{a}$ Department of Chemistry and Biochemistry, University of Munich, Germany \\ ${ }^{b}$ Department of Chemistry, University of Munich, Butenandtstr. 5-13, D-81 377 München, \\ Germany \\ E-mail:H.Noeth@lrz.uni-muenchen.de
}

Dedicated to Prof. Dr. Rosalinda Contreras Theurel on the occasion of her $60^{\text {th }}$ birthday

\begin{abstract}
Borazines of type $\mathrm{R}_{3} \mathrm{~B}_{3} \mathrm{~N}_{3} \mathrm{H}_{3}(\mathrm{R}=\mathrm{Me}$, Et, i-Pr, $t-\mathrm{Bu}, \mathrm{Ph})$ add $\mathrm{AlBr}_{3}$ and $\mathrm{GaCl}_{3}$ in a 1:1 ratio to one of its $\mathrm{N}$ atoms. During this process the planarity of the borazine is lost. The ring system of the adducts show a semi chair conformation. $\mathrm{HBr}$ gas reacts with $\mathrm{R}_{3} \mathrm{~B}_{3} \mathrm{~N}_{3} \mathrm{H}_{3} \cdot \mathrm{AlBr}_{3}$ in toluene with formation of hitherto unknown borazinium tetrabromo aluminates $\left(\mathrm{R}_{3} \mathrm{~B}_{3} \mathrm{~N}_{3} \mathrm{H}_{4}\right)^{+}\left(\mathrm{AlBr}_{4}\right)$. The ring system of the cation is almost planar but it shows like the adducts three different B-N bond lengths.
\end{abstract}

Keywords: 2,4,6-Triorganylborazine $\mathrm{EX}_{3}$ Adducts, 2,4,6-triorganylborazinium salts, IR, NMR, $\mathrm{X}$-ray structures

\section{Introduction}

Borazines are isoelectronic and isolobal with benzenes but their chemical reactivity is grossly different. $^{2-5}$ This is due to the inherent B-N bond polarity which places a partial negative charge on the nitrogen atoms and a partial positive charge on the boron atoms. For example: borazine $(\mathrm{HB}=\mathrm{NH})_{3}$ adds 3 equivalents of $\mathrm{HBr}$ or $\mathrm{HCl}$ to form the cycloborazane $\left[\mathrm{H}(\mathrm{X}) \mathrm{B}-\mathrm{NH}_{2}\right]_{3}{ }^{6}$ and $\mathrm{HCl}$ adds to $(\mathrm{ClB}=\mathrm{NMe})_{3}$ with formation of $\left(\mathrm{Cl}_{2} \mathrm{~B}-\mathrm{NHMe}\right)_{3}{ }^{7}$

While $\mathrm{BCl}_{3}$ or $\mathrm{BBr}_{3}$ give no adducts with borazines of type $(\mathrm{HB}=\mathrm{NH})_{3},(\mathrm{HB}=\mathrm{NR})_{3}$ or $\left(\mathrm{R}^{\prime} \mathrm{B}=\mathrm{NR}\right)_{3}$ they induce substitution reactions at the boron atoms with formation of $\mathrm{B}$ haloborazines. ${ }^{8}$ In contrast, $\mathrm{AlX}_{3}(\mathrm{X}=\mathrm{Cl}, \mathrm{Br})$ forms stable $1: 1$ adducts with $(\mathrm{MeB}=\mathrm{NMe})_{3}{ }^{9}$ while $\mathrm{SnCl}_{4}$ reacts with $(\mathrm{HB}=\mathrm{NR})_{3}$ by an $\mathrm{H} / \mathrm{Cl}$ exchange. ${ }^{10}$ One can speculate whether the 
addition of $\mathrm{HCl}$ to a borazine occurs stepwise with the first step being the formation of a borazinium cation $\mathrm{R}_{3} \mathrm{~B}_{3} \mathrm{~N}_{3} \mathrm{H}_{4}{ }^{+}$. So far, this kind of borazinium cation is presently unknown. As we will show here, cations of this type are readily accessible.

\section{Synthesis and characterization of $\mathrm{EX}_{3}$ adducts of borazines}

Synthesis. Adducts 1 to $\mathbf{1 0}$ can be prepared by reacting equivalent amounts of the respective borazine with either $\mathrm{AlBr}_{3}$ or $\mathrm{GaCl}_{3}$ in toluene as shown in Eq. (1). Yields ranged from $45 \%$ to $100 \%$ (see experimental part):<smiles>[R]B1NB([R])N([R])B([R])N1</smiles>
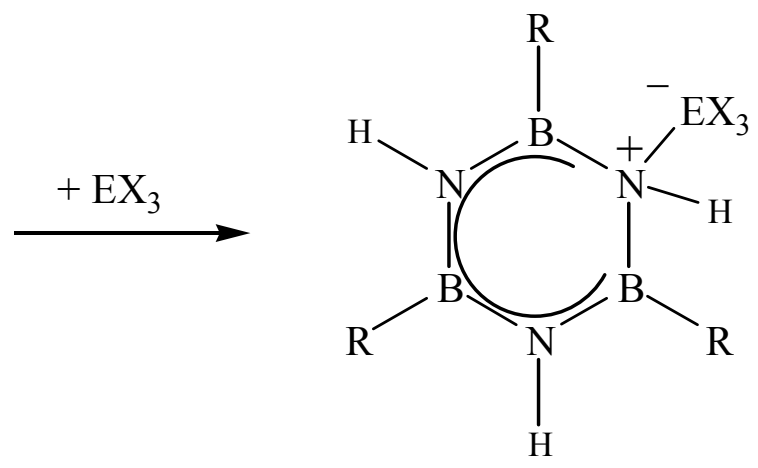

$$
\begin{aligned}
& 1 \mathrm{R}=\mathrm{Me}, \mathrm{EX}_{3}=\mathrm{AlBr}_{3} \\
& 2 \mathrm{R}=\mathrm{Ph}, \mathrm{EX}_{3}=\mathrm{AlBr}_{3} \\
& 3 \mathrm{R}=\mathrm{Et}, \quad \mathrm{EX}_{3}=\mathrm{AlBr}_{3} \\
& 4 \mathrm{R}=i \text {-Pr, } \mathrm{EX}_{3}=\mathrm{AlBr}_{3} \\
& 5 \mathrm{R}=t-\mathrm{Bu}, \mathrm{EX}_{3}=\mathrm{AlBr}_{3} \\
& 6 \mathrm{R}=\mathrm{Me}, \mathrm{EX}_{3}=\mathrm{GaCl}_{3} \\
& 7 \mathrm{R}=\mathrm{Ph}, \mathrm{EX}_{3}=\mathrm{GaCl}_{3} \\
& 8 \mathrm{R}=\mathrm{Et}, \quad \mathrm{EX}_{3}=\mathrm{GaCl}_{3} \\
& 9 \mathrm{R}=i \text {-Pr, } \mathrm{EX}_{3}=\mathrm{GaCl}_{3} \\
& 10 \mathrm{R}=t-\mathrm{Bu}, \mathrm{EX}_{3}=\mathrm{GaCl}_{3}
\end{aligned}
$$

Compounds 2 - 5 and 8 crystallized in tiny needles or very thin plates. These crystals were, however, unsuitable for a crystal structure determination in contrast to well shape crystals of compounds 1, 6, 7 and $\mathbf{1 0}$.

NMR spectroscopy. Table 1 contains NMR data of compounds 1 to 10 . In all cases the ${ }^{11} \mathrm{~B}$ resonances are at lower field than the parent borazines. The ${ }^{11} \mathrm{~B}$ nuclei of the $\mathrm{AlBr}_{3}$ adducts are deshielded compared with the $\mathrm{GaCl}_{3}$ adducts indicating that $\mathrm{AlBr}_{3}$ seems to be a stronger Lewis acid than $\mathrm{GaCl}_{3}$. One should note that only a single ${ }^{11} \mathrm{~B}$ resonance signal is observed for all these compounds at ambient temperature although two are expected with an intensity ratio of $2: 1$. This suggests that the $\mathrm{EX}_{3}$ part in these compounds is fluxional at room temperature. This is 
supported by the ${ }^{1} \mathrm{H}$ NMR data: only one set of signals for the B-organyl groups is observed instead of the expected two. At $-80^{\circ} \mathrm{C}$, however, two ${ }^{11} \mathrm{~B}$ NMR signals at $\delta=38.6$ and $42.4 \mathrm{ppm}$ and two ${ }^{1} \mathrm{H}$ NMR signals at $\delta=0.18$ and $0.36 \mathrm{ppm}$ (intensity ratiol : 2) are observed for compound 1.

Table 1. Chemical shifts for ${ }^{11} \mathrm{~B},{ }^{27} \mathrm{Al}$ and ${ }^{1} \mathrm{H}$ (in ppm) of the parent borazines and their $\mathrm{AlBr}_{3}$ or $\mathrm{GaCl}_{3} 1: 1$ adducts in $\mathrm{C}_{6} \mathrm{D}_{6}$

\begin{tabular}{lccc}
\hline Compound & $\delta^{11} \mathrm{~B}$ & $\delta^{27} \mathrm{Al}$ & $\delta^{1} \mathrm{H}$ \\
\hline $\mathrm{MeB}=\mathrm{NH})_{3}$ & 36.0 & & 0.23 \\
$(\mathrm{MeB}=\mathrm{NH})_{3} \mathrm{AlBr}_{3}, \mathbf{1}$ & 38.4 & 107.8 & 0.31 \\
$(\mathrm{MeB}=\mathrm{NH})_{3} \mathrm{GaCl}_{3}, \mathbf{6}$ & 40.5 & & 0.19 \\
$(\mathrm{PhB}=\mathrm{NH})_{3}$ & 34.8 & & $7.28-7.53$ \\
$(\mathrm{PhB}=\mathrm{NH})_{3} \mathrm{AlBr}_{3}, \mathbf{2}$ & 37.6 & 97.1 & $6.99-7.55$ \\
$(\mathrm{PhB}=\mathrm{NH})_{3} \mathrm{GaCl}_{3} .7$ & 36.9 & & $7.17-7.57$ \\
$(\mathrm{EtB}=\mathrm{NH})_{3}$ & 35.4 & & $0.77 \mathrm{q} ., 0.94 \mathrm{t}$ \\
$(\mathrm{EtB}=\mathrm{NH})_{3} \mathrm{AlBr}_{3}, \mathbf{3}$ & 42.6 & 96.0 & $0.85 \mathrm{q}, 0.99 \mathrm{t}$ \\
$(\mathrm{EtB}=\mathrm{NH})_{3} \mathrm{GaCl}_{3}, \mathbf{8}$ & 41.9 & & $0.78 \mathrm{q}, 0.97 \mathrm{t}$ \\
$(\mathrm{iPrB}=\mathrm{NH})_{3}$ & 37.4 & & $0.36 \mathrm{sept}, 1.25 \mathrm{~d}$ \\
$(\mathrm{iPrB}=\mathrm{NH})_{3} \mathrm{AlBr}_{3}, \mathbf{4}$ & 43.6 & 95.9 & $0.46 \mathrm{sept}, 1.19 \mathrm{~d}$ \\
$(\mathrm{iPrB}=\mathrm{NH})_{3} \mathrm{GaCl}_{3}, \mathbf{9}$ & 40.5 & & $0.38 \mathrm{sept}, 1.13 \mathrm{~d}$ \\
$(t-\mathrm{BuB}=\mathrm{NH})_{3}$ & 37.1 & & $0.98 \mathrm{~s}$ \\
$(t-\mathrm{BuB}=\mathrm{NH})_{3} \mathrm{AlBr}_{3}, \mathbf{5}$ & 42.4 & 95.6 & $1.00 \mathrm{~s}$ \\
$(t-\mathrm{BuB}=\mathrm{NH})_{3} \mathrm{GaCl}_{3}, \mathbf{1 0}$ & 40.8 & & $1.01 \mathrm{~s}$ \\
\hline
\end{tabular}

The protons of the alkyl groups are deshielded relative to the parent borazines. This is to be expected because the $\mathrm{EX}_{3}$ group removes electron density from the borazine rings. Except for compounds 1 and 6 the protons of the $\mathrm{GaCl}_{3}$ adducts are less deshielded than the $\mathrm{AlBr}_{3}$ adducts supporting the already mentioned conclusion that $\mathrm{AlBr}_{3}$ is the stronger Lewis acid. However, in case of adducts 1 and $\mathbf{6}$ this order is reversed. A similar behaviour has been observed for $\mathrm{AlBr}_{3}$ and $\mathrm{GaCl}_{3}$ adducts of aminoboranes. ${ }^{11}$

The Al nuclei of the adducts 1 to 5 are deshielded by 10 to $20 \mathrm{ppm}$ with respect to $\mathrm{Al}_{2} \mathrm{Br}_{6 .}{ }^{11}$ The fairly large difference in the shielding of the ${ }^{27} \mathrm{Al}$ nucleus between $(\mathrm{MeB}=\mathrm{NH})_{3}-\mathrm{AlBr}_{3}$ and the other members of the $(\mathrm{RB}=\mathrm{NH})_{3} \mathrm{AlBr}_{3}$ series is most likely not a steric effect because in this case the shift difference should increase in the order $\mathrm{Et}<\mathrm{i}-\mathrm{Pr}<\mathrm{t}-\mathrm{Bu}$. It may be that the $\mathrm{N}$ atoms of trimethylborazine unit are more basic than in the other trialkylborazines. This would fit with the NMR shift for the triphenylborazine- $\mathrm{AlBr}_{3}$ adduct 2.

IR spectroscopy. The IR spectra of adducts 1 to $\mathbf{1 0}$ show many bands. The most intense bands are cited in table 2. Two or three NH stretching bands are expected for the adducts. The NH band of the tetra-coordinated nitrogen atom should be at lower wave number than those of the tri-co- 
ordinated $\mathrm{N}$ atom. One can note that the positions of these bands are almost unaffected whether $\mathrm{AlBr}_{3}$ or $\mathrm{GaCl}_{3}$ is coordinated. Characteristic IR bands for the $\mathrm{BN}$ vibrations of borazines have already been summarized. ${ }^{2}$ They are found in the region from 1480 to $1300 \mathrm{~cm}^{-1}$. For each pair of $(\mathrm{RB}=\mathrm{NH})_{3} \mathrm{EX}_{3}\left(\mathrm{EX}_{3}=\mathrm{AlBr}_{3}, \mathrm{GaCl}_{3}\right)$ compounds the strongest band at highest wave numbers (1562 to $1506 \mathrm{~cm}^{-1}$ ) stems from a $\mathrm{GaCl}_{3}$ adduct. The largest difference is found for the t-butyl derivatives 5 and 10. However, we could not find a proper assignment for the $\mathrm{B}_{2} \mathrm{~N}$ vibrations of the tetra-coordinated N1 atoms. Also, only a tentative assignment is made for the N-E- stretching bands. The difference in the wave number between pairs of $\mathrm{AlBr}_{3} / \mathrm{GaCl}_{3}$ compounds is largest with $99 \mathrm{~cm}^{-1}$ while the difference for most others is in the order of 50 to $60 \mathrm{~cm}^{-1}$.

Table 2. Selected IR bands $\left(\mathrm{cm}^{-1}\right)$ of the $\mathrm{AlBr}_{3}$ and $\mathrm{GaCl}_{3} 1: 1$ adducts of borazines $(\mathrm{RB}=\mathrm{NH})_{3}$

\begin{tabular}{|c|c|c|c|c|c|}
\hline Compound & $v \mathrm{NH}$ & $v \mathrm{CH}$ & $v \mathrm{BN}$ & $v \mathrm{NE}$ & $v \mathrm{EX}_{3}$ \\
\hline$(\mathrm{MeB}=\mathrm{NH})_{3} \mathrm{AlBr}_{3}, \mathbf{1}$ & $\begin{array}{l}3447,3415, \\
3406\end{array}$ & 2970,2945 & $\begin{array}{l}1509, \\
1497,1475\end{array}$ & 496,486 & 430.383 \\
\hline$(\mathrm{MeB}=\mathrm{NH})_{3} \mathrm{GaCl}_{3}, 6$ & 3447,3409 & 2978,2950 & $\begin{array}{l}1511,1499 \\
1439\end{array}$ & 437,428 & 404. 375 \\
\hline$(\mathrm{PhB}=\mathrm{NH})_{3} \mathrm{AlBr}_{3}, 2$ & 3437,3420 & $\begin{array}{l}3076,3053, \\
3015\end{array}$ & 1506,1473 & 506,472 & 430,399 \\
\hline$(\mathrm{PhB}=\mathrm{NH})_{3} \mathrm{GaCl}_{3}, 7$ & 3432,2420 & $\begin{array}{l}3080,3056, \\
3015\end{array}$ & 1509,1476 & 447 & $\begin{array}{l}411360, \\
339\end{array}$ \\
\hline$(\mathrm{EtB}=\mathrm{NH})_{3} \mathrm{AlBr}_{3}, 3$ & 32442,2292 & $\begin{array}{l}2963,2920, \\
2877\end{array}$ & 1521,1490 & 495 & $\begin{array}{l}418,399, \\
367,\end{array}$ \\
\hline$(\mathrm{EtB}=\mathrm{NH})_{3} \mathrm{GaCl}_{3}, \mathbf{8}$ & 3446,3393 & $\begin{array}{l}2963,2920, \\
2877\end{array}$ & $\begin{array}{l}1523,1489, \\
1446,\end{array}$ & 446 & $\begin{array}{l}394,377, \\
343\end{array}$ \\
\hline$(\mathrm{iPrB}=\mathrm{NH})_{3} \mathrm{AlBr}_{3}, 4$ & 3445,3424 & $\begin{array}{l}2053,2902, \\
2877\end{array}$ & 1519,1480 & 500,476 & 420,399 \\
\hline$(\mathrm{iPrB}=\mathrm{NH})_{3} \mathrm{GaCl}_{3}, 9$ & 3444,3424 & $\begin{array}{l}2953,2900, \\
2869\end{array}$ & $1525 \mathrm{~m} 1491$ & & $\begin{array}{l}408,394, \\
361\end{array}$ \\
\hline$(t \mathrm{BuB}=\mathrm{NH})_{3} \mathrm{AlBr}_{3}, 5$ & $\begin{array}{l}3456,3416, \\
3405\end{array}$ & $\begin{array}{l}2950,2891, \\
2865\end{array}$ & $\begin{array}{l}1533,1495 \\
1485\end{array}$ & $\begin{array}{l}491, \\
473,464\end{array}$ & $\begin{array}{l}414,365, \\
336\end{array}$ \\
\hline$(t \mathrm{BuB}=\mathrm{NH})_{3} \mathrm{GaCl}_{3}, \mathbf{1 0}$ & 3542,3422 & $\begin{array}{l}2940,2892, \\
2863\end{array}$ & $\begin{array}{l}1562,1495, \\
1486\end{array}$ & 392 & $\begin{array}{l}392,380, \\
367\end{array}$ \\
\hline
\end{tabular}

Structures of the adduct molecules. Single crystals have been obtained for the $\mathrm{AlBr}_{3}$ adduct 1 , and of the $\mathrm{GaCl}_{3}$ adducts 6, 7 and 10. Relevant bond lengths and bond angles are listed in Table 3 together with the data for $(\mathrm{MeB}=\mathrm{NMe})_{3} \mathrm{AlBr}_{3}{ }^{9}$ although these data are less accurate. Figures 1,$2 ; 3$ and 4 show the molecular structures of these four adducts. It should be noted that the crystals of compound 6 have the composition $(\mathrm{MeB}=\mathrm{NH})_{3} \mathrm{GaCl}_{3} \mathrm{MePh}$. They contain a site disordered toluene molecule. The addition of $\mathrm{AlBr}_{3}$ or $\mathrm{GaCl}_{3}$ to borazines $(\mathrm{RB}=\mathrm{NH})_{3}$ changes the ring planarity of the borazines into a semichair conformation with the $\mathrm{EX}_{3}$ coordinated $\mathrm{N} 1$ atom 
moving above the B1 to B3 five-membered part of the six-membered ring. Particularly noticeable is compound 10 where these 5 atoms are slightly twisted out of the mean plane through $\mathrm{B} 1$ to $\mathrm{B} 3$ as shown by the respective torsion angles. The interplanar angles between $\mathrm{B} 1 \mathrm{~N} 1 \mathrm{~B} 3$ and $\mathrm{B} 1 \mathrm{~N} 2 \mathrm{~B} 2 \mathrm{~N} 3 \mathrm{~B} 3$ vary from $22.1^{\circ}$ for $\mathbf{6}$ to $28.0^{\circ}$ for $\mathbf{1 0}$. This locates the $\mathrm{Al}$ atom or the Ga atoms 0.323 (1), 0.292 (6), 0.353 (7) and 0.375 (10) $\AA$ above the B1N2B2N3B3 plane, respectively.

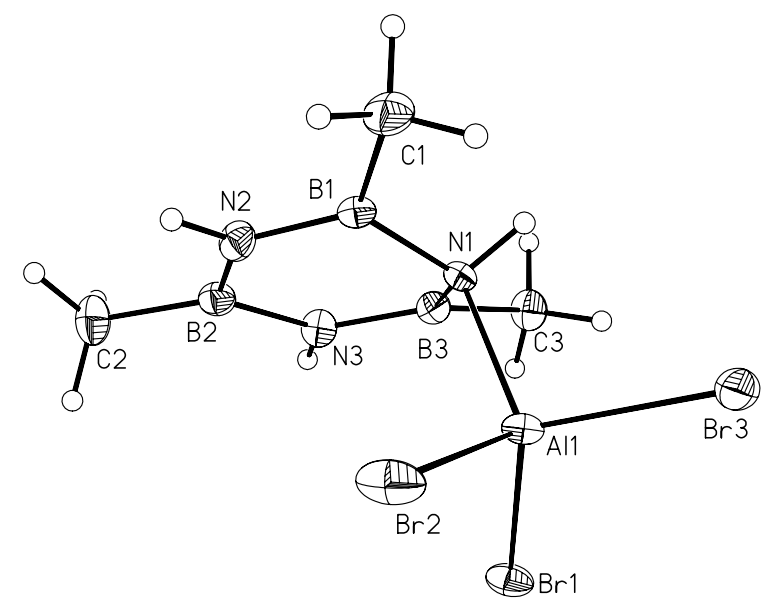

Figure 1a. ORTEP plot of compound 1.

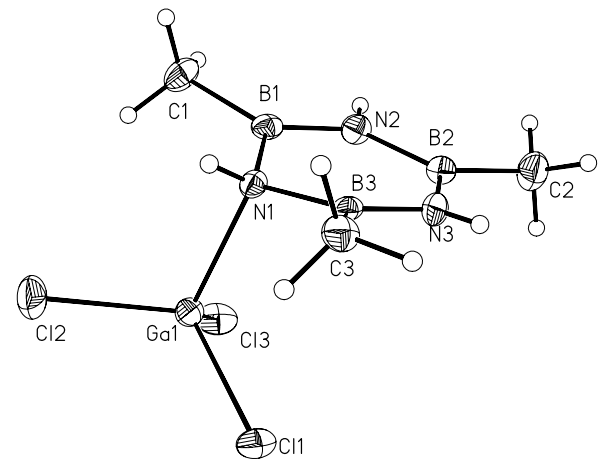

Figure 2. ORTEP plot of compound 6.

Adduct formation at $\mathrm{N} 1$ leads to a B-N bond lengthening from 1.504 up to $1.526 \AA$ as expected for tetra-coordinated $\mathrm{N}$ atoms. Within the $3 \sigma$ criterion these bonds can be considered ofalmost equal lengths. This formation of the tetra-coordinated $\mathrm{N} 1$ atom induces two different pairs of B-N bond lengths for B1-N2 and B3-N3 on the one hand and N2-B2 and B2-N3 on the other hand. The first pair is significantly shorter than the second pair whose lengths correspond nicely with BN bond lengths determined in borazines (1.41 to $1.43 \AA$ ). ${ }^{13}$ 


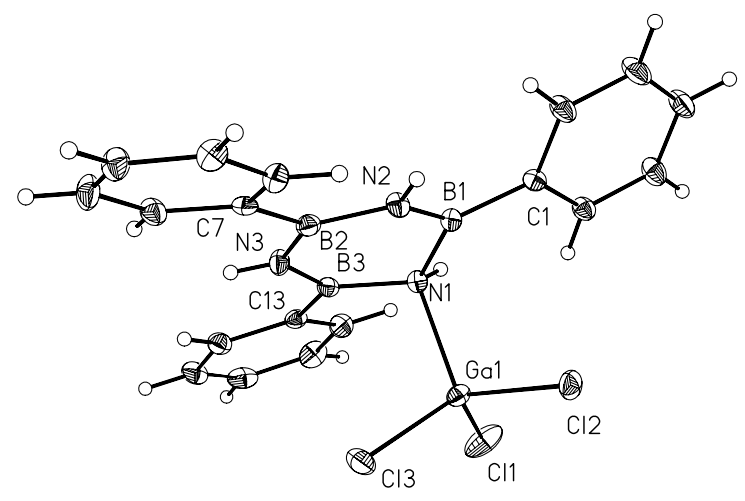

Figure 3. ORTEP plot of compound 7.

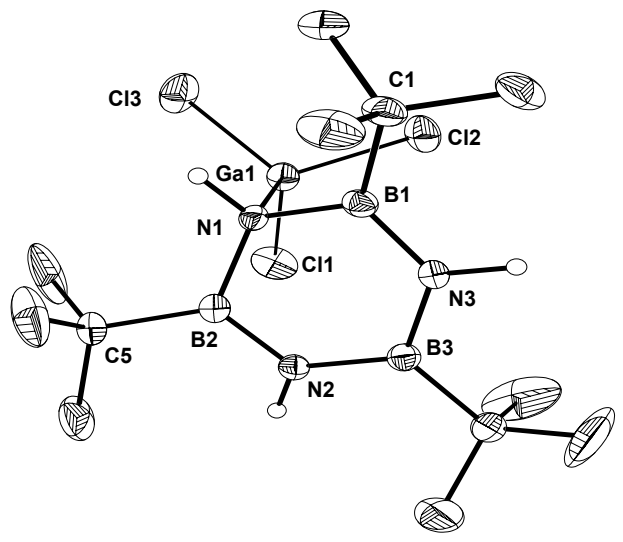

Figure 4. ORTEP plot of compound $\mathbf{1 0 .}$

Another feature which is a consequence of the asymmetry induced by atom N1 is that the endocylic bond angles at the boron atoms and atoms $\mathrm{N} 2$ and N3 deviate significantly from $120^{\circ}$. The B1-N1-B3 bond angles range from 117.2 to $118.8^{\circ}$ which deviate by 7.3 to $8.9^{\circ}$ from the ideal tetrahedral bond angles. But more significant are the changes for the N-B-N bond angles at the $\mathrm{B}$ atoms which are quite acute with 113.4 to $115.4^{\circ}$. On the other hand, B-N-B bond angles at atoms $\mathrm{N} 2$ and $\mathrm{N} 3$ are wide with an average close to $126^{\circ}$.

The semichair conformation has still another consequence. The carbon atoms bonded to atoms $\mathrm{B} 1$ and $\mathrm{B} 3$ are sitting below the $\mathrm{B} 1 \mathrm{~N} 2 \mathrm{~B} 2 \mathrm{~N} 3$ plane as shown by the interplanar angle between the planes $\mathrm{N} 3 \mathrm{~B} 3 \mathrm{C} 11 \mathrm{~N} 1$ and $\mathrm{N} 1 \mathrm{~B} 1 \mathrm{~N} 2 \mathrm{~B} 2 \mathrm{~N} 3 \mathrm{~B} 3$ of $7.0^{\circ}$ for $\mathbf{1}, 11.0^{\circ}$ for $\mathbf{6}, 8.5^{\circ}$ for 7 and $17.7^{\circ}$ for $\mathbf{1 0 .}$ 
Table 3. Selected bond lengths $(\AA)$ and bond angles $\left(^{\circ}\right)$ of compounds $\mathbf{1 , ~ 6 , 9}$ and $\mathbf{1 0}$ as well as of $(\mathrm{MeB}=\mathrm{NMe})_{3} \mathrm{AlBr}_{3}$

\begin{tabular}{|c|c|c|c|c|c|}
\hline Compound & 1 & 6 & 7 & 10 & $\left(\mathrm{Me}_{3} \mathrm{~B}_{3} \mathrm{~N}_{3} \mathrm{Me}_{3}\right) \mathrm{AlBr}_{3}{ }^{9}$ \\
\hline N1-B1 & $1.522(6)$ & $1.511(5)$ & $1.522(6)$ & $1.505(5)$ & $1.52(2)$ \\
\hline B1-N2 & $1.403(7)$ & $1.390(5)$ & $1.410(6)$ & $1.401(5)$ & $1.40(2)$ \\
\hline N2-B2 & $1.436(8)$ & $1.447(5)$ & $1.441(6)$ & $1.431(5)$ & $1.44(2)$ \\
\hline $\mathrm{B} 2-\mathrm{N} 3$ & $1.443(7)$ & $1.435(4)$ & $1.437(7)$ & $1.444(4)$ & $1.41(2)$ \\
\hline N3-B3 & $1.397(7)$ & $1.401(5)$ & $1.398(7)$ & $1.401(5)$ & $1.39(1)$ \\
\hline B3-N1 & $1.504(7)$ & $1.520(4)$ & $1.510(5)$ & $1.526(4)$ & $1.54(2)$ \\
\hline B1-N1-B3 & $117.9(4)$ & $118.8(3)$ & $118.1(4)$ & $117.2(2)$ & $109.5(19)$ \\
\hline N1-B1-N2 & $114.5(4)$ & $115.4(3)$ & $113.4(4)$ & $114.5(3)$ & $118(1)$ \\
\hline B1-N2-B2 & $125.7(4)$ & $125.9(3)$ & $125.3(4)$ & $125.4(3)$ & $120(1)$ \\
\hline N2-B2-N3 & $115.4(5)$ & $114.9(3)$ & $115.2(4)$ & $114.9(3)$ & $117(1)$ \\
\hline B2-N3-B3 & $125.5(5)$ & $126.6(3)$ & $125.9(4)$ & $126.3(3)$ & $124(1)$ \\
\hline N3-B3-N1 & $115.0(4)$ & $113.6(3)$ & $114.9(4)$ & $114.3(3)$ & $114(1)$ \\
\hline N1-E-X1 & $108.0(1)$ & $110.2(1)$ & $103.3(1)$ & $108.16(8)$ & \\
\hline N1-E-X2 & $109.6(1)$ & $104.6(1)$ & $108.1(1)$ & $107.68(8)$ & \\
\hline N1-E-X3 & $105.6(1)$ & $113.6(5)$ & $108.0(1)$ & $103.04(9)$ & \\
\hline
\end{tabular}

Figure 1b. $\mathrm{H}{ }^{*} \mathrm{Br}$ and $\mathrm{Br} " \mathrm{Br}$ contacts between molecules $\mathbf{1}$.

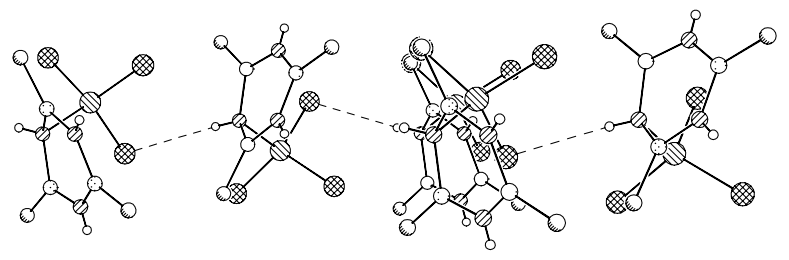

Figure 2b. $\mathrm{N}-\mathrm{H} \cdot \mathrm{Cl}$ hydrogen bonds in between molecules 6.

In the solid state the molecules of 1 are associated via a $\mathrm{N}-\mathrm{H}^{\cdots} \mathrm{Br}$ bridges to two different $\mathrm{AlBr}_{3}$ molecules forming a chain structure (see Figure $1 \mathrm{~b}$ ) and similar $\mathrm{N}-\mathrm{H}^{\cdots} \mathrm{Cl}$ bridge bonds are found in compound 6 (Figure $2 \mathrm{~b}$ ). There is no hydrogen bond interaction between the NH group 
and a $\mathrm{Cl}$ atom in $(\mathrm{PhB}=\mathrm{NH})_{3} \mathrm{GaCl}_{3}, 7$, but there are three in compound $\mathbf{1 0}$. One shows a $\mathrm{H}^{\prime \prime} \mathrm{Cl}$ distance of $2.77 \AA$ and an $\mathrm{N}-\mathrm{H}-\mathrm{Cl}$ bond angle of $170.5^{\circ}$, the other $\mathrm{H}$ atoms binds to two $\mathrm{Cl}$ atoms of the same $\mathrm{GaCl}_{3}$ unit with $\mathrm{H}^{*} \mathrm{Cl}$ distances of 2.98 and $2.72 \AA$ and $\mathrm{N}-\mathrm{H}{ }^{*} \mathrm{Cl}$ angles of 133.9 and $138.6^{\circ}$.

\section{2,4,6-Triorganylborazinium tetrabromoaluminates}

Synthesis. There are several options for generating borazinium salts: i) by replacement of a boron bonded halogen atom as a halide by a strong neutral nucleophile as shown in Eq. (2), -ii) by heterolytic cleavage of a boron halogen bond with a strong halide acceptor as depicted in Eq. (3); and iii) by addition of a proton to an $\mathrm{N}$ atom of neutral borazines as indicated in Eq. (4).<smiles>[R]B1NB(N)N([Tl])B([R])N1[Tl]</smiles><smiles></smiles>

(3) $\mathrm{Nu}$<smiles></smiles>

+ Halide acceptor $\mathrm{ECl}_{\mathrm{n}}$

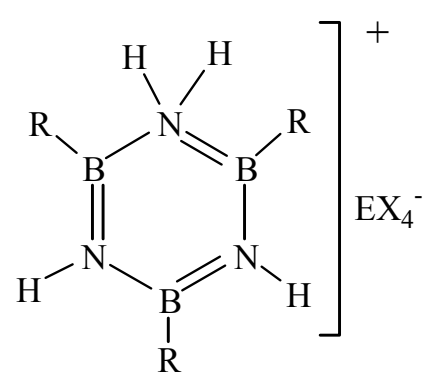

(4)

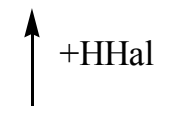

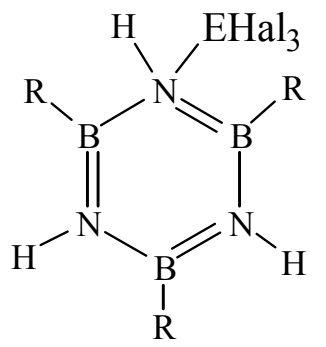

\begin{tabular}{ccc}
$\mathrm{R}$ & $\mathrm{Et}$ & $t \mathrm{Bu}$ \\
\hline $\mathrm{E}$ & $\mathrm{Al}$ & $\mathrm{Al}$ \\
$\mathrm{X}$ & $\mathrm{Br}$ & $\mathrm{Br}$ \\
\hline $\mathbf{1 1}$ & $\mathbf{1 2}$
\end{tabular}

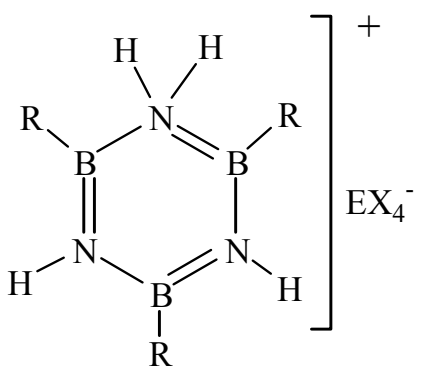

Amongst these reactions (3) is most likely not favored because a borazinium ion with a dicoordinated boron atom would be generated and this will be accompanied by an increased steric strain. A reaction as shown in Equ. (2) has been observed in the reaction of 2,4,6trichloroborazine with pyridine. Up to 4 molecules of pyridine can add to trichloroborazine $(\mathrm{ClB}=\mathrm{NH})_{3}$. The nature of these adducts have so far not been characterized. ${ }^{15-17}$ except for the 
1:5 adduct which has been structurally characterized as a penta(pyridine)borazinium ${ }^{3+}$ trichloride. ${ }^{17}$ It is also well known that borazines add hydrogen halides up to a $1: 3$ ratio. The latter are cyclotriborazanes $\left[\mathrm{R}(\mathrm{Hal}) \mathrm{B}-\mathrm{NH}_{2}\right]_{3} .{ }^{18}$ Therefore, the formation of borazinium ions is obviously not favored. However, its formation can be expected when the halide anion is replaced by a less nucleophilic and larger anion. From this point of view one may expect that trifluromethylsulfonic acid would be a candidate for borazinium salt formation, as well as $\mathrm{HSbF}_{6}$ or $\mathrm{H}\left[\mathrm{Al}(\mathrm{Hal})_{4}\right]$. In this study we reacted $\mathrm{HBr}$ with the borazine aluminium tribromide adducts 3 and $\mathbf{5}$ in toluene in order to generate the comparatively large tetrabromoaluminate. We observed a reaction according to Eq. (4). Compounds 11 and 12 were obtained as single crystals suitable for an X-ray structure determination.

NMR and IR spectra. The IR spectra of the borazinium salts 11 and 12 (see table 4) show more bands in the $\mathrm{NH}$ and $\mathrm{NB}$ region than the $\mathrm{EX}_{3}$ adducts $\mathbf{1}-10$. In 11 and 12 we have one $\mathrm{NH}_{2}$ group and two NH groups. The former should lead to two IR bands ( $v_{\text {as }}$ and $v_{\text {sym }}$ ), the other two may either be degenerate or - if combined - can also lead to two bands at higher wave numbers. Actually, only two bands were located for $\mathbf{1 1}$ but four for 12. In the region of the BN valence bonds four strong band were observed for $\mathbf{1 1}$ but only three for $\mathbf{1 2}$. We assign the bands at lower wave numbers to the $\mathrm{NB}_{2}$ vibration of the tetracoordinated $\mathrm{N}$ atom, the others to the remaining $\mathrm{BN}$ ring atoms. The strongest bands for the parent borazines are $1485 \mathrm{~cm}^{-1}$ for $(\mathrm{RB}=\mathrm{NH})_{3}(\mathrm{R}=$ $\mathrm{Me}, \mathrm{Et}, \mathrm{Bu})$ and $1472 \mathrm{~cm}^{-1}$ for $(\mathrm{PhB}=\mathrm{NH})_{3} .{ }^{5} \mathrm{So}$, the high frequency data at 1533, 1520 for 11 and $1518 \mathrm{~cm}^{-1}$ for 12 indicates stronger BN bonding for the planar B1 to B3 part of the borazinyl cation. The strong band at $423 \mathrm{~cm}^{-1}$ is typical for the $\mathrm{AlBr}_{4}$ anion.

Table 4. Selected IR bands (wave numbers in $\mathrm{cm}^{-1}$ ) for the borazinium salts $\mathbf{1 1}$ and $\mathbf{1 2}$ recorded as hostaflon/nujol mulls

\begin{tabular}{lllll}
\hline Compound & $v(\mathrm{NH})$ & $v(\mathrm{CH})$ & $v(\mathrm{BN})$ & $v(\mathrm{AlBr})$ \\
\hline$\left[\mathrm{Et}_{3} \mathrm{~B}_{3} \mathrm{~N}_{3} \mathrm{H}_{4}\right] \mathrm{AlBr}_{4}, \mathbf{1 1}$ & 3392 & $2943,2962,2928$, & 1533,1492, & $424 \mathrm{st}$ \\
& & 2878 & 1463 & \\
& & $2942,2891,2864$ & 1518.1486, & $423 \mathrm{st}$ \\
{$\left[\mathrm{Bu}_{3} \mathrm{~B}_{3} \mathrm{~N}_{3} \mathrm{H}_{4}\right] \mathrm{AlBr}_{4}, \mathbf{1 2}$} & $3415 \mathrm{~m}, 3403 \mathrm{st}$, & $294 \mathrm{st}$ & & 1459 \\
& 2754 & \\
\hline
\end{tabular}

Table 5. ${ }^{11} \mathrm{~B},{ }^{1} \mathrm{H}$ and ${ }^{27} \mathrm{Al}$ chemical shifts of the borazinium tetrabromoaluminates $(\delta$ in ppm)

\begin{tabular}{|c|c|c|c|}
\hline Compound & $\delta^{11} \mathrm{~B}$ & $\delta^{1} \mathrm{H}$ & $\delta^{27} \mathrm{Al}$ \\
\hline$\left[\mathrm{Et}_{3} \mathrm{~B}_{3} \mathrm{~N}_{3} \mathrm{H}_{4}\right] \mathrm{AlBr}_{4}, \mathbf{1 1}$ & $36.9,38.0$ & $\begin{array}{l}0.81,1 . .03\left(\mathrm{q}, \mathrm{BCH}_{2} 0.94\right. \\
\left(\mathrm{t}, \mathrm{CH}_{2} \mathrm{CH}_{3}\right) 4.65(\mathrm{NH})(\end{array}$ & 84.6 \\
\hline$\left[t \mathrm{Bu}_{3} \mathrm{~B}_{3} \mathrm{~N}_{3} \mathrm{H}_{4}\right] \mathrm{AlBr}_{4}, \mathbf{1 2}$ & $37.9,44.2$ & $1.01 \mathrm{CH}_{3}, 4.58(\mathrm{NH})$ & 84.3 \\
\hline
\end{tabular}

Table 5 summarizes NMR shifts for the two borazinium tetrabromoaluminates. Compared with the $\delta{ }^{11} \mathrm{~B}$ data for the respective $\mathrm{AlBr}_{3}$ adducts $\mathbf{3}$ and $\mathbf{5}$ the boron nuclei of $\mathbf{1 1}$ and $\mathbf{1 2}$ are 
better shielded by 5.7 and $4.7 \mathrm{ppm}$ in $\mathbf{1 1}$ and -1.8 and $4.5 \mathrm{ppm}$ for $\mathbf{1 2}$. In contrast, the ${ }^{1} \mathrm{H}$ NMR data reveal two different $\mathrm{CH}_{2} \mathrm{~B}$ groups in $\mathbf{1 1}$ but only one $\mathrm{CH}_{3}$ group. The intensity ratio for these three signals is $4: 2: 9$. Obviously the signals for the $\mathrm{CH}_{3}$ groups show the same chemical shift. On the other hand, only a single ${ }^{1} \mathrm{H}$ NMR signal is found for the tert.-butyl groups in $\mathbf{1 2}$. This observation fits with a fluxional behaviour. For both borazinium cations only a single broad proton resonance for the $\mathrm{NH}$ groups is observed at 4.65 and 4.38 for $\mathbf{1 1}$ and $\mathbf{1 2}$ respectively. The tetrabromoaluminate ion is represented by a sharp signal at $84.5 \mathrm{ppm} .{ }^{13}$

Molecular structures. The borazinium salt 11 crystallizes in rectangular platelets. They are orthorhombic, space group $P \mathrm{ca}_{1}, \mathrm{Z}=4$. The colorless prisms of compound $\mathbf{1 2}$ are also orthorhombic, space group $P$ na $2_{1}, Z=4$. Relevant bonding parameters for both compounds are listed in Table 6. Figures 5a and 6a show the molecular units. The six membered borazinium rings are almost planar.

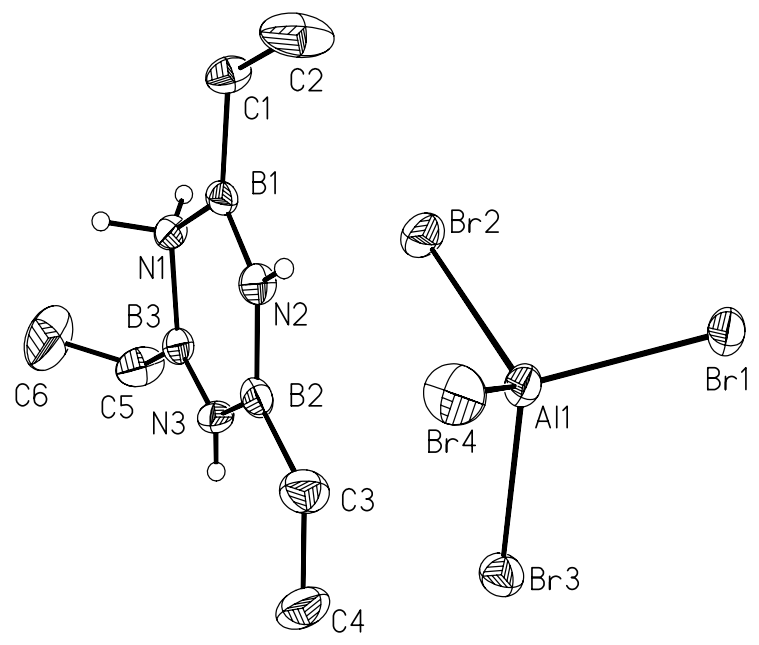

Figure 5a. ORTEP plot of compound $11 \mathrm{CH}$ atoms omitted. 


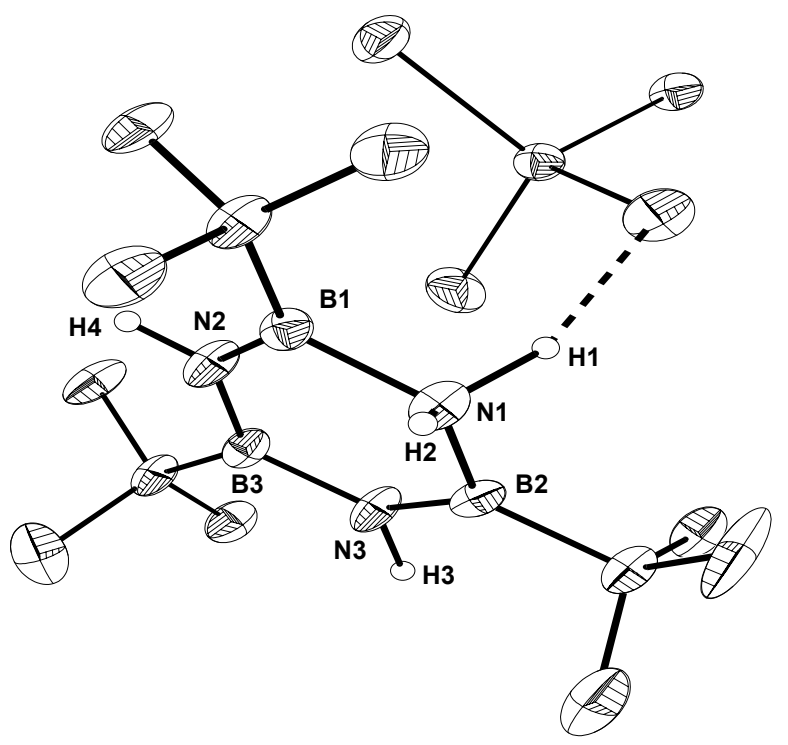

Figure 6a. ORTEP plot of compound $12 \mathrm{CH}$ atoms omitted.

Table 6. Selected bond lengths and bond angles of the borazinium tetrabromoaluminates $\mathbf{1 1}$ and 12

\begin{tabular}{llllll}
\hline Compound & $\mathbf{1 1}$ & $\mathbf{1 2}$ & & $\mathbf{1 1}$ & $\mathbf{1 2}$ \\
\hline B1-N1 & $1.56(1)$ & $1.56(1)$ & B1-N1-B3 & $118.4(7)$ & $122.4(6)$ \\
B1-N2 & $1.38(1)$ & $1.37(1))$ & N1-B1-N2 & $115.8(7)$ & $112.1(7)$ \\
B2-N2 & $1.44(1)$ & $1.42(1)$ & B1-N2-B2 & $124.8(8)$ & $129.9(7)$ \\
B2-N3 & $1.43(1)$ & $1.46(1)$ & N2-B2-N3 & $118.8(8)$ & $114.4(7)$ \\
B3-N3 & $1.36(1)$ & $1.39(1)$ & B2-N3-B3 & $127.4(8)$ & $127.3(7)$ \\
B3-N1 & $1.56(1)$ & $1.52(1)$ & N3-B3-N1 & $114.7(9)$ & $113.7(7)$ \\
A11-Br1 & $2,299(2)$ & $2.296(3)$ & Br1-A11-Br2 & $106.5(1)$ & $107.9(1)$ \\
A11-Br2 & $2.295(3)$ & $2.295(3)$ & Br2-A11-Br3 & $110.6(1)$ & $111.0(1)$ \\
Al1-Br3 & $2.292(3)$ & $2.264(3)$ & Br1-A11-Br3 & $107.2(1)$ & $111.9(1)$ \\
Al1-Br4 & $2.270(3)$ & $2.311(2)$ & Br1-A11-Br4 & $106.6(1)$ & $106.5(1)$ \\
\hline
\end{tabular}

The B1-N1-B3 plane forms an interplanar angle with the other BN atoms of $8.9^{\circ}$ for $\mathbf{1 1}$ and $4.2^{\circ}$ for 12. The arrangement of the Et groups in $\mathbf{1 1}$ are asymmetric and reduces the point group symmetry to $C_{1}$. The angles for N2-B2-C3 and N3-B2-C3 differ by $4.3^{\circ}$, while those of N1-B3$\mathrm{C} 5$ and N3-B3-C5 differ by $11.1^{\circ}$ similar to the difference of bond angles for N1-B1-C1 and N2$\mathrm{B} 1-\mathrm{C} 1$ of $12.2^{\circ}$. While the ethyl group at atoms $\mathrm{B} 1$ and $\mathrm{B} 2$ are almost coplanar with the ring the torsion angle $\mathrm{C} 6-\mathrm{C} 5-\mathrm{B} 3-\mathrm{N} 1$ is $53.5^{\circ}$ and the torsion angle $\mathrm{C} 6-\mathrm{C} 5-\mathrm{B} 3-\mathrm{N} 3122.9^{\circ}$.

The effect of the protonation of the borazine rings is the same as for the addition of $\mathrm{EX}_{3}$ molecules: The N1-B bonds are long $(1.56 \AA)$, the adjacent $\mathrm{BN}$ bonds are short and the B-N 
bond to the para-B2 atom is typical for borazines. This indicates that the borazinium cation has lost its pseudoaromatic character. Also the endocyclic ring angles correspond with those of the adducts. The alterations are larger for the 2,4,6-tri(t-butyl)borazinium cation than for the ethyl derivative, most likely a steric effect. The N1 atom in 11 lays $0.119 \AA$ above the ring plane, and in case of $120.085 \AA$. All other ring atoms are less than $0.09 \AA$ apart from the mean plane through atoms B1N2B2N3B3.

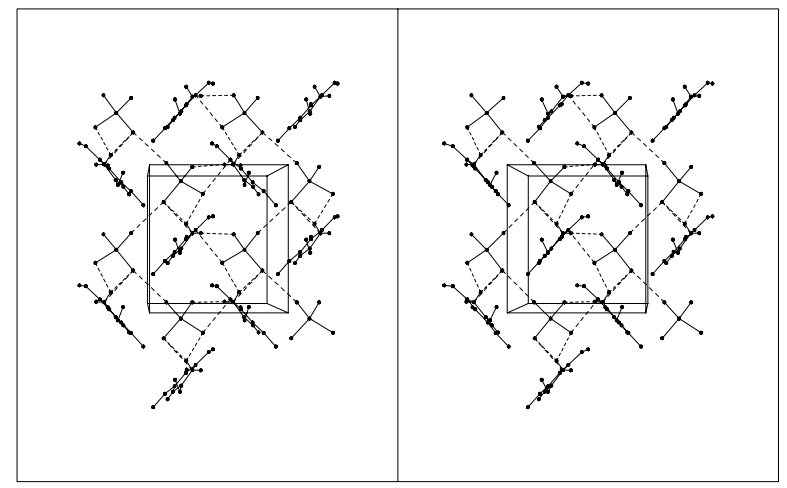

Figure 5b. Stereoplot of the unit cell of compound 11 showing $\mathrm{N}-\mathrm{H} * \mathrm{Br}$ interaction down the baxis.

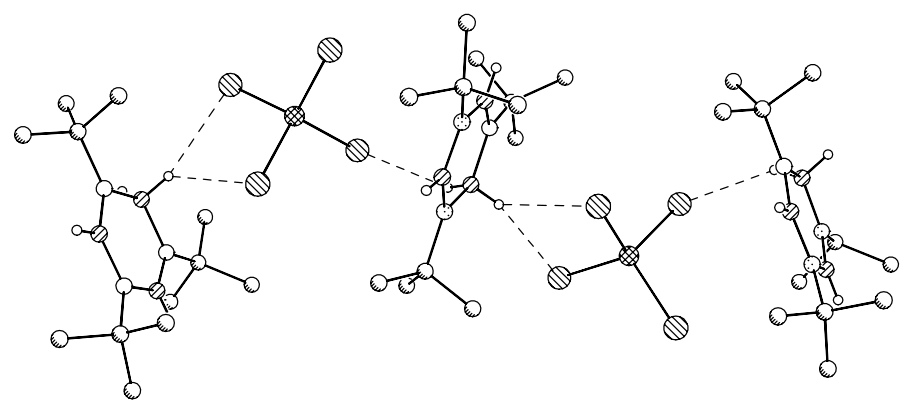

Figure 6b. Part of the chain structure of compound 11, view down.

\section{Discussion}

Borazines of type $(\mathrm{RB}=\mathrm{NH})_{3}$ add readily $\mathrm{AlBr}_{3}$ and $\mathrm{GaCl}_{3}$ in a 1:1 ratio. But even more interesting is the fact that the $\mathrm{AlBr}_{3}$ adducts react with $\mathrm{HBr}$ to form the hitherto unknown borazinium salts $\left[\mathrm{R}_{3} \mathrm{~B}_{3} \mathrm{MN}_{3} \mathrm{H}_{4}\right] \mathrm{AlBr}_{4}$. There is a close structural relationships between the adducts and the borazinium cations. The BN bonds to the tetra-coordinated nitrogen atom N1 are long (aver. $1.56 \AA$ ). The adjacent two BN bonds are rather short (aver. $1.38 \AA$ ) while the BN 
bonds to atom $\mathrm{B} 2$ in para position resemble those of borazines. ${ }^{14-19}$ However, the $\mathrm{B}_{3} \mathrm{~N}_{3}$ rings of the $\mathrm{EX}_{3}$ adducts possess a semichair conformation while the rings of the two borazinyl cations are almost planar. This corresponds with ab initio calculations for the cation $\mathrm{H}_{3} \mathrm{~B}_{3} \mathrm{~N}_{3} \mathrm{H}_{4}{ }^{+}{ }^{20}$ The N1-B bond lengths of the borazinium cations are about 3\% larger than in the adducts and fall already into the range for amine borane adducts $(1.58-1.64 \AA)$, while those of B1-N2 and B3N3 are already close to aminoboranes (1.36 $\AA$ ).

As pointed out, the B1-N1-B3 bond angle is rather wide for a tetracoordinated $\mathrm{N}$ atom, but they are close to the calculated value for the parent borazinium cation $\left(118.0^{\circ}\right) .{ }^{20}$ The molecular parameters of the cation in compound $\mathbf{1 2}$ deviate approximately by $3^{\circ}$ from the calculated values. This is due to the influence of the rather bulky $t$-butyl group.

A consequence of the semichair conformation of the adducts $\mathbf{1}$ to $\mathbf{1 0}$ is that the boron bonded $\mathrm{C}$ atoms are bent in the opposite direction of atom N1. The organyl groups at atoms B1 and B3 in the $\mathrm{AlBr}_{3}$ adducts are more strongly bent backwards than in the $\mathrm{GaCl}_{3}$ adducts. This may be due to the longer Ga-N bonds, although the lengths difference to the Al-N bond is fairly small. The longer B-N bonds to atom N1 and the open B1-N1-B3 bond angle results in an increase of the $\mathrm{B} 1-\mathrm{B} 3$ distance. Consequently the B1-N2 and B3-N3 bonds are no longer parallel to one another.

The ready formation of compounds 11 and 12 suggests that borazinium ions of type $\mathrm{R}_{3} \mathrm{~B}_{3} \mathrm{~N}_{3} \mathrm{H}_{4}{ }^{+}$are readily accessible, provided that a suitable anion is present. Such anions can be $\mathrm{SbCl}_{6}{ }^{-}, \mathrm{O}_{3} \mathrm{SCF}_{3}{ }^{-}$, or $\mathrm{Al}\left(\mathrm{OC}_{4} \mathrm{~F}_{9}\right)_{4}{ }_{4}^{-}$. It needs to be shown that also borazines of type $\left(\mathrm{RB}=\mathrm{NR}^{\prime}\right)_{3}$ can be protonated, maybe not only with formation of $\mathrm{R}_{3} \mathrm{~B}_{3} \mathrm{~N}_{3} \mathrm{R}_{3} \mathrm{H}^{+}$but also of $\mathrm{R}_{3} \mathrm{~B}_{3} \mathrm{~N}_{3} \mathrm{R}_{3} \mathrm{H}_{2}{ }^{2+}$ or even $\mathrm{R}_{3} \mathrm{~B}_{3} \mathrm{~N}_{3} \mathrm{R}_{3} \mathrm{H}_{3}{ }^{3+}$. This is not an unlikely possibility as triply charged borazinium salts have already been reported. Typical examples are $\left[\mathrm{Et}_{3} \mathrm{P}-\mathrm{N}=\mathrm{BH}\right]_{3}{ }^{3+}{ }^{21}$ and $\left[\left(\mathrm{HBNPEt}_{2}{ }_{4} \mathrm{NPEt}_{3}\right]^{3+} 22\right.$.

\section{Experimental Section}

General Procedures. All experiments have been performed under anhydrous conditions using the Schlenk technique with dinitrogen as the protecting gas. The borazines have been prepared by procedures described in the literature. ${ }^{5}$ Commercial $\mathrm{GaCl}_{3}$ and $\mathrm{AlBr}_{3}$ were sublimed before use. Solvents were dried by conventional methods. NMR spectra were recorded on JEOL 270 and 400 instruments using TMS $\left({ }^{1} \mathrm{H},{ }^{13} \mathrm{C}\right)$ as an internal standard, and $\mathrm{BF}_{3} \mathrm{OEt}_{2}$ and a $1 \mathrm{M} \mathrm{AlCl}_{3}$ aqueous solution as external standards. $\mathrm{C}_{6} \mathrm{D}_{6}$ was used as solvent. A Siemens P4 diffractometer equipped with an area detector and a low temperature device was used for data collection. If not otherwise stated data collection was performed at $-80{ }^{\circ} \mathrm{C}$ with $\mathrm{MoK} \alpha$ radiation and a graphite monochromator. The thermal ellipsoids shown in the figures represent a $25 \%$ probability. Elemental analysis was performed at the microanalytical laboratory of the department.

2,4,6-Trimethylborazine- $N$-aluminum tribromide (1). To a stirred solution of $(\mathrm{MeB}=\mathrm{NH})_{3}$ $(0.92 \mathrm{~g}, 7.44 \mathrm{mmol})$ in toluene $(50 \mathrm{~mL})$ was added a solution of $\mathrm{AlBr}_{3}(2.01 \mathrm{~g} .7 .44 \mathrm{mmol})$ in toluene $(20 \mathrm{~mL})$ at $-78{ }^{\circ} \mathrm{C}$. A white precipitate formed which dissolved on warming to room 
temperature. Rectangular platelets separated within a week from the solution which was kept at 4 ${ }^{\circ} \mathrm{C}$. Yield: 2.98 g (97 \%); m. p. $79-83{ }^{\circ} \mathrm{C} . \mathrm{C}_{3} \mathrm{H}_{12} \mathrm{~N}_{3} \mathrm{AlB}_{3} \mathrm{Br}_{3}$ (389.72): calc. C 9.26, H 3.11, N 10.79; found C 8.92, H 2.84, N 10.61.

2,4,6-Triphenylborazine- $\mathrm{N}$-aluminium tribromide (2). Prepared from $(\mathrm{PhB}=\mathrm{NH})_{3}(0.68 \mathrm{~g}, 2.2$ $\mathrm{mmol})$ and $\mathrm{AlBr}_{3}(0.64 \mathrm{~g}, 2.2 \mathrm{mmol})$ in toluene $(50+20 \mathrm{~mL})$. A microcrystalline powder formed. No single crystals resulted on crystallization from hexane, hot toluene or $\mathrm{CH}_{2} \mathrm{Cl}_{2}$. Yield: 1.21 g (91.7 \%), m. p. $145^{\circ} \mathrm{C}$ dec. ${ }^{13} \mathrm{C}$ NMR. $\delta=127.4,128.7,130.4,132.5,133.8,137.6$. $\mathrm{C}_{18} \mathrm{H}_{18} \mathrm{~N}_{3} \mathrm{AlB}_{3} \mathrm{Br}_{3}$ (575.46): calc. C 37.57, $\mathrm{H}$ 7.30, N 3.15; found C 37.30, H 7.03, N 3.08.

2,4,6-Triethylborazine- $\boldsymbol{N}$-aluminium tribromide (3). Prepared as described for $\mathbf{1}$ from $(\mathrm{EtB}=\mathrm{NH})_{3}(0.61 \mathrm{~g}, 3.7 \mathrm{mmol})$ in toluene $(15 \mathrm{~mL})$ and $\mathrm{AlBr}_{3}(0.99 \mathrm{~g}, 3.66 \mathrm{mmol})$ in toluene $(20$ $\mathrm{mL})$ at ambient temperature. A turbid solution formed which was filtered. After reducing the volume of the filtrate to $1 / 3^{\text {rd }}$ small crystals separated. Attempts to recrystallize from hexane or $\mathrm{CH}_{2} \mathrm{Cl}_{2}$ gave no crystals suitable for X-ray structure determination. Yield: $1.15 \mathrm{~g}(72 \%)$;, m. p. 88 - $90^{\circ}$ C. $\mathrm{C}_{6} \mathrm{H}_{14} \mathrm{~N}_{3} \mathrm{AlB}_{3} \mathrm{Br}_{3}$ (431.33): calc. C 16.71, H 4.21, N 9.71, Br 55.57: found: C 16.07, $\mathrm{H} 4.38, \mathrm{~N} 9.50, \mathrm{Br} 54.34$.

2,4,6-Triisopropylborazine- $\mathrm{N}$-aluminium tribromide (4). Prepared fro $(i \mathrm{PrB}=\mathrm{NH})_{3}(0.68 \mathrm{~g}$, $3.3 \mathrm{mmol})$ in toluene $(15 \mathrm{~mL})$ and $\mathrm{AlBr}_{3}(0.88 \mathrm{~g}, 3.3 \mathrm{mmol})$ in toluene $(20 \mathrm{~mL})$. The solution was reduced in vacuo to $1 / 3^{\text {rd }}$ of its original volume. Small platelets separated at $4{ }^{\circ} \mathrm{C}$ but no single crystals were obtained from hexane or $\mathrm{CH}_{2} \mathrm{Cl}_{2}$. Yield: $1.00 \mathrm{~g}(65 \%)$. M. p. 95 - $97^{\circ} \mathrm{C}$.

$\mathrm{C}_{9} \mathrm{H}_{24} \mathrm{~N}_{3} \mathrm{AlB}_{3} \mathrm{Br}_{3}$ (473.42): calc. C 22.81, H 5.11, N 8.86, Br 50.63; found C 22.48, H 5.25, N 8.94, Br 50.63; found C 21.96, H 5.24, N 8,30, Br 50.25.

2,4,6-Tri(tert-butyl)borazine- $\mathrm{N}$-aluminium tribromide (5). Obtained from $(t \mathrm{BuB}=\mathrm{NH})_{3}(1.45$ $\mathrm{g}, 6.62 \mathrm{mmol})$ and $\mathrm{AlBr}_{3}(1.50 \mathrm{~g}, 5.62 \mathrm{mmol})$ in toluene $(20+20 \mathrm{~mL})$. Colorless needles separated on storing the solution at $4{ }^{\circ} \mathrm{C}$. Yield: $1.30 \mathrm{~g}(45 \%)$., m. p. $120-121^{\circ} \mathrm{C}$.

$\mathrm{C}_{12} \mathrm{H}_{30} \mathrm{~N}_{3} \mathrm{AlB}_{3} \mathrm{Br}_{3}$ (515.51): calc. C 27.96, H 5.87, N 8.15, Br 46.50; found C 27.59, H 6.00, N 7.83, $\mathrm{Br} 45.88$.

2,4,6-Trimethylborazine- $N$-gallium trichloride(6). At $-78^{\circ} \mathrm{C}$ a solution of $\mathrm{GaCl}_{3}(1.56 \mathrm{~g}, 8.88$ $\mathrm{mmol})$ in toluene $(20 \mathrm{~mL})$ was added while stirring to a solution of $(\mathrm{MeB}=\mathrm{NH})_{3}$ in toluene $(1.09$ $\mathrm{g}, 8.88 \mathrm{mmol}, 20 \mathrm{~mL}$ ). At ambient temperature about $60 \%$ of the solvent was removed in vacuo. Single crystals separated at $-25{ }^{\circ} \mathrm{C}$ within a week. Yield: $2.65 \mathrm{~g}(99 \%)$; m.p. $109-111^{\circ} \mathrm{C}$. $\mathrm{C}_{3} \mathrm{H}_{12} \mathrm{~N}_{3} \mathrm{~B}_{3} \mathrm{Cl}_{3} \mathrm{Ga}$ (298.64): Calc. C 12.11, H 3.72, N 14.12; found C 11.91, H 3.76, N 13.89.

2,4,6-Triphenylborazine- $N$-gallium trichloride(7). To stirred toluene solution $(30 \mathrm{~mL})$ of $(\mathrm{PhB}=\mathrm{NH})_{3}(230 \mathrm{mg}, 0.751 \mathrm{mmol})$ was added at $-78{ }^{\circ} \mathrm{C}$ slowly a solution of $\mathrm{GaCl}_{3}(120 \mathrm{mg}$, $0.75 \mathrm{mmol})$ in toluene $(10 \mathrm{~mL})$. A white precipitate formed which dissolved at ambient temperature. At $5{ }^{\circ} \mathrm{C}$ colorless rhombic crystals separated with in a few days. Yield: $0.36 \mathrm{~g}$ (100 \%), m. p. $285{ }^{\circ} \mathrm{C}$ dec. $\mathrm{C}_{18} \mathrm{H}_{18} \mathrm{~N}_{3} \mathrm{~B}_{3} \mathrm{Cl}_{3} \mathrm{Ga}$ (484.85): calc. C 44.59, $\mathrm{H}$ 3.74, $\mathrm{N}$ 8.67; found: $\mathrm{C} 43.17$, H 3.30, N 8.35.

2,4,6-Triethylborazine-N-gallium trichloride $(8)$. To a stirred solution of $(\mathrm{EtB}=\mathrm{NH})_{3}(0.58 \mathrm{~g}$, $3.5 \mathrm{mmol})$ in toluene $(10 \mathrm{~mL})$ was added a toluene solution of $\mathrm{GaCl}_{3}(0.62 \mathrm{~g}, 3.5 \mathrm{mmol}, 20 \mathrm{~mL})$. A turbid solution formed which was filtered. After about $25 \mathrm{ml}$ of toluene had been removed in 
vacuo crystals separated at $4{ }^{\circ} \mathrm{C}$ from the slightly green colored solution. Yield: $0.67 \mathrm{~g}(80 \%)$,

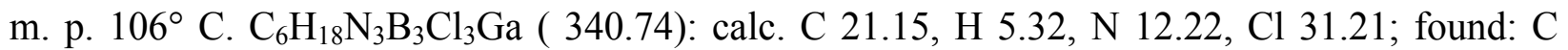
20.83, H 5.16, N 11.78, Cl 31.62.

2,4,6-Triisopropylborazine- $\boldsymbol{N}$-gallium trichloride(9).Prepared in analogy to $\mathbf{6}$ from $(\mathrm{iPrB}=\mathrm{NH})_{3}(0.380 \mathrm{~g}, 2.14 \mathrm{mmol})$ and $\mathrm{GaCl}_{3}(0.441 \mathrm{~g}, 2.14 \mathrm{mmol})$ in toluene $(20+10 \mathrm{~mL})$. Colourless needles separated at $4^{\circ} \mathrm{C}$. Yield $0.67 \mathrm{~g},(82 \%), 61-63^{\circ} \mathrm{C}$.

$\mathrm{C}_{9} \mathrm{H}_{24} \mathrm{~N}_{3} \mathrm{~B}_{3} \mathrm{Cl}_{3} \mathrm{Ga}$ (382.92): calc.: C 28.24, $\mathrm{H}$ 6.32, $\mathrm{N} 10.98, \mathrm{Cl} 27.78$; found $\mathrm{C} 28.13, \mathrm{H} 6.31, \mathrm{~N}$ 10.59, $\mathrm{Cl} 28.03$.

2,4,6-Tri-(tert-butyl)borazine- $\boldsymbol{N}$-gallium trichloride (10). Prepared from $(t \mathrm{BuB}=\mathrm{NH})_{3}(0.91 \mathrm{~g}$, $3.53 \mathrm{mmol})$ and $\mathrm{GaCl}_{3}(0.62,3.53 \mathrm{mmol})$ in toluene $(10+20 \mathrm{~mL})$. After removal of $27 \mathrm{ml}$ of toluene in vacuo crystals separated from the solution at $4^{\circ} \mathrm{C}$ in large needles. Yield: $1.30 \mathrm{~g}(85$ \%), m. p. $88-90^{\circ}$ C. $\mathrm{C}_{12} \mathrm{H}_{30} \mathrm{~N}_{3} \mathrm{~B}_{3} \mathrm{Cl}_{3} \mathrm{Ga}$ (424.90): calc. C 33.92, $\mathrm{H}$ 7.11, N 9.89, $\mathrm{Cl} 25.03$; found: C 31.00, $\mathrm{H} 6.54, \mathrm{~N} 9.59, \mathrm{Cl} 25.76$.

2,4,6-Triethylborazinium-tetrabromoaluminate(11). $\mathrm{HBr}$, which was generated form $\mathrm{NaBr}$ (100 mg, $1.0 \mathrm{mmol}$ ) and $85 \% \mathrm{H}_{3} \mathrm{PO}_{4}$, was passed via a septum needle into a solution of $(\mathrm{EtB}=\mathrm{NH})_{3} \mathrm{AlBr}_{3}(9.44 \mathrm{~g}, 1.02 \mathrm{mmol})$ in toluene $(10 \mathrm{~mL})$. After all $\mathrm{HBr}$ has been swept from the $\mathrm{HBr}$ generator into the toluene solution of the $(\mathrm{EtB}=\mathrm{NH})_{3} \mathrm{AlBr}_{3}$ with $\mathrm{N}_{2}$, stirring was continued for additional $2 \mathrm{~h}$. The slightly turbid solution was cleared by filtration. The filtrate was then kept at $4{ }^{\circ} \mathrm{C}$. Colorless platelets separated within a few days. Yield: $0.25 \mathrm{~g}(50 \%)$., m. p. $121{ }^{\circ} \mathrm{C}$ dec. $\mathrm{C}_{6} \mathrm{H}_{19} \mathrm{~N}_{3} \mathrm{AlB}_{3} \mathrm{Br}_{4}$ (512.25): C 14.07, H 3.75, N 8.20, Br 62.39: found; C 14.27, H 3.97, N 8.29, $\mathrm{Br} 61.11$.

2,4,6-Tri(tert-butyl)borazinium-tetrabromoaluminate (12). Prepared as 11 from $\mathrm{HBr}$ (generated by reacting $\mathrm{NaBr}(133 \mathrm{mg}, 1.3 \mathrm{mmol})$ with $\left.85 \% \mathrm{H}_{3} \mathrm{PO}_{4}\right)$ and a toluene solution (30 $\mathrm{mL})$ of $(t \mathrm{Bu}=\mathrm{NH})_{3} \mathrm{AlBr}_{3}(670 \mathrm{mg}, 1.30 \mathrm{mmol})$. The slightly yellow filtrate was kept at $4{ }^{\circ} \mathrm{C}$ for 4 d. Colorless platelets formed. Yield: $470 \mathrm{mg}(60 \%)$, m. p. $185{ }^{\circ} \mathrm{C} . \mathrm{C}_{12} \mathrm{H}_{31} \mathrm{~N}_{3} \mathrm{AlB}_{3} \mathrm{Br}_{4}(596.41)$ : calc.: C 24.61 H 5.24, N 7.05, Br 63.59; found: C 24.23, H 5.27, N 6.98, Br 62.99.

X-Ray structure determinations. Under $\mathrm{N}_{2}$ cover crystals were placed in a polyfluoro ether oil cooled to $-25{ }^{\circ} \mathrm{C}$. The selected crystal was fixed on a glass fibre with this oil and placed on a goniometer head which was flushed with $\mathrm{N}_{2}$ cooled to $-80^{\circ} \mathrm{C}$. The unit cell parameters were determined from the reflection on 5 sets of 15 exposures by using the program SMART. Data collection was performed in a the hemisphere mode by changing $\omega$ in $0.3^{\circ}$ intervals and $10 \mathrm{~s}$ exposure time.. Data on 1200 frames were reduced with the programme SAINT. Structure solution was performed with SHELXTL after absorption correction (ABSO). Data referring to crystallography and structure solution are listed in Table 6. Additional data have been deposited with the Cambridge Crystallographic Data Centre, CCDC 647497 to 647 502. Copies of the data can be obtained free of charge on application to The Director, CCDC, 12 Union Road, Cambridge CB2 1EZ. UK (Fax int. code+(1223)336-033; e-mail: deposit@ccdc.cam.uk). 
Table 6. Crystal data and data related to data collection and structure solution

\begin{tabular}{|c|c|c|c|c|c|c|}
\hline Compound & 1 & 6 & 7 & 10 & 11 & 12 \\
\hline \multirow[t]{2}{*}{ Chem. formula } & $\mathrm{C}_{3} \mathrm{H}_{12} \mathrm{~N}_{3} \mathrm{AlB}_{3}$ & $\mathrm{C}_{3} \mathrm{H}_{12} \mathrm{~N}_{3} \mathrm{~B}_{3} \mathrm{Cl}_{3} \mathrm{G}$ & $\mathrm{C}_{18} \mathrm{H}_{18} \mathrm{~N}_{3} \mathrm{~B}_{3} \mathrm{Cl}_{3}$ & $\mathrm{C}_{12} \mathrm{H}_{30} \mathrm{~N}_{3} \mathrm{~B}_{3} \mathrm{Cl}_{3}$ & $\mathrm{C}_{6} \mathrm{H}_{15} \mathrm{~N}_{3} \mathrm{AlB}_{3} \mathrm{~B}$ & $3 \mathrm{C}_{12} \mathrm{H}_{31} \mathrm{~N}_{3} \mathrm{Al}$ \\
\hline & $\mathrm{Br}_{3}$ & $\mathrm{a}$ & $\mathrm{Ga}$ & $\mathrm{Ga}$ & $\mathrm{r}_{4}$ & $\mathrm{~B}_{3} \mathrm{Br}_{4}$ \\
\hline Form. wght. & 389.30 & 390.79 & 484.85 & 424.89 & 508.26 & 596.45 \\
\hline Cry. size [mm] & $0.20 \times 0.20 \times 0.30$ & $0.10 \times 0.20 \times 0.30$ & $0.18 \times 0.24 \times 0.28$ & $0.20 \times 0.20 \times 0.30$ & $0.18 \times 0.22 \times 0.32$ & $0.2 \times 0-3 \times 0-3$ \\
\hline Cryst. system & Monoclinic & Monoclinic & Orthorhombic & Monoclinc & Orthorhombic & Orthorhombic \\
\hline Space group & $P 2_{1} / \mathrm{n}$ & $P 2_{1} / \mathrm{c}$ & $P$ na $2_{1}$ & $P 2_{2} / \mathrm{n}$ & Pca2(1) & $P$ na $2_{1}$ \\
\hline $\mathrm{a},[\AA]$ & $8.7266(1)$ & $13.9729(2)$ & $13-9729(2)$ & $16.998(1)$ & $16.2301(2)$ & $18.400(2)$ \\
\hline $\mathrm{b},[\AA]$ & $14.8792(1)$ & $15.0518(3)$ & $9.0853(2)$ & $9.8995(8)$ & $10.211(1)$ & $10.400(2)$ \\
\hline $\mathrm{c},[\AA]$ & $10.9407(1)$ & $11.6272(2)$ & $17.9358(3)$ & $13.455(1)$ & $10.974(1)$ & $13.090(2)$ \\
\hline$\alpha,\left[^{\circ}\right]$ & 90 & 90 & 90 & 90 & 90 & 90 \\
\hline$B,\left[^{\circ}\right]$ & $107.410(1)$ & $114.008(1)$ & 90 & $102.353(1)$ & 90 & 90 \\
\hline$\gamma,\left[{ }^{\circ}\right]$ & 90 & 90 & 90 & 90 & 90 & 90 \\
\hline $\mathrm{V},\left[\AA^{3}\right]$ & $1355.5(3)$ & $1859.12(6)$ & $2162.66(7)$ & $2211.8(3)$ & $1818.8(3)$ & $2504.9(6)$ \\
\hline Z & 4 & 4 & 4 & 4 & 4 & 4 \\
\hline$\rho$ (calcd.), $\left[\mathrm{Mg} / \mathrm{m}^{3}\right]$ & 1.908 & 1.396 & 1.489 & 1.267 & 1.856 & 1.582 \\
\hline$\mu\left[\mathrm{mm}^{-1}\right]$ & 8.956 & 1.902 & 1.652 & 1.604 & 8.882 & 6.462 \\
\hline $\mathrm{F}(000)$ & 736 & 792 & 976 & 880 & 960 & 1168 \\
\hline \multirow[t]{3}{*}{ Index range } & $-11 \leq \mathrm{h} \leq 11$ & $-14 \leq h \leq 14$ & $-18 \leq \mathrm{h} \leq 18$ & $-22 \leq \mathrm{h} \leq 15$ & $-20 \leq \mathrm{h} \leq 20$ & $-17 \leq \mathrm{h} \leq 17$ \\
\hline & $-19 \leq \mathrm{k} \leq 19$ & $-18 \leq \mathrm{k} \leq 18$ & $-10 \leq \mathrm{k} \leq 11$ & $-12 \leq \mathrm{k} \leq 12$ & $-13 \leq k \leq 13$ & $-13 \leq \mathrm{k} \leq 13$ \\
\hline & $-14 \leq 1 \leq 13$ & $-11 \leq 1 \leq 15$ & $-21 \leq 1 \leq 20$ & $-17 \leq 1 \leq 17$ & $-14 \leq 1 \leq 11$ & $-16 \leq 1 \leq 16$ \\
\hline $2 \theta\left[^{\circ}\right]$ & 58.86 & 57.68 & 28.14 & 57.22 & 56.88 & 55.46 \\
\hline Temp, $[\mathrm{K}]$ & $183(2)$ & $193(2)$ & $183(2)$ & $193(2)$ & 193(2) & $193(2)$ \\
\hline Refl. collected & 7890 & 10533 & 11782 & 6162 & 9880 & 13364 \\
\hline Refl. unique & 2671 & 3245 & 4340 & 3395 & 3624 & 4749 \\
\hline Refl. obs. $(4 \sigma)$ & 2139 & 2761 & 3604 & 3433 & 2464 & 2444 \\
\hline R (int.) & 0.0314 & 0.0340 & 0.0387 & 0-0199 & 0.0549 & 0.0719 \\
\hline No. variables & 121 & 297 & 262 & 211 & 157 & 217 \\
\hline Wght. ${ }^{1} \mathrm{x} / \mathrm{y}$ & $0.0853 / 1,7218$ & $0.2391 / 2.5906$ & $0.0556 / 0.2196$ & $0.0637 / 0.0707$ & $0.0544 / 0.00$ & \\
\hline GOOF & 1.086 & $1-125$ & 1.086 & 0.886 & 0.938 & 0.881 \\
\hline Final R $(4 \sigma)$ & 0.0388 & 0.0393 & 0.0429 & 0.349 & 0.0460 & 0.0479 \\
\hline Final wR2 & 0.1107 & 0.0844 & $0-0958$ & 0.996 & 0.0883 & $0-0894$ \\
\hline Larg. res.[e/ $\left./ \AA^{3}\right]$ & 1.394 & 0.590 & 0.774 & 0.527 & 0.636 & 0.702 \\
\hline
\end{tabular}

$1 \mathrm{w}^{-1}=\sigma^{2} \mathrm{~F}_{\mathrm{o}}^{2}+(\mathrm{xP})^{2}+\mathrm{yP} ; \mathrm{P}=\left(\mathrm{F}_{\mathrm{o}}^{2}+2 \mathrm{~F}_{\mathrm{c}}^{2}\right) / 3$ 


\section{Acknowledgements}

We thank Mr. P. Mayer for recording many NMR spectra and Dr. T. Habereder, Dr. J.Knizek and Dr. M. Warchold for X-ray data collection. IR spectra were recorded with the help of Mrs. E. Hanatschek and G. Kiesewetter. This studay was supported by Chemetall GmbH, Frankfurt and Fonds der Chemischen Industrie, Frankfurt. Thanks to all of them for their help.

\section{References}

1. Contribution to the Chemistry of Boron, 267. For Contribution 266 see Jetzfellner, R.; Nöth, H.; Paine, R. T. Z. Anorg. Allg. Chem. 2007, 633, 917

2. Steinberg, H.; Brotherton, R. J. Organoboron Chemistry, 1966, 2, Chapter 8

3. Armitage, D. A. Inorganic Rings and Cages, E. Arnold Publ., 1972.

4. Haiduc, I. The Chemistry of Inorganic Ring Systems, Wiley Interscience: London, New York, Sydney, Toronto, 1970.

5. Gmelin, Handbook of Inorganic Chemistry, $8^{\text {th }}$ Edition, 1978, Vol. 17; 1980, Vol.2 $1^{\text {st. }}$ Supplm.; 1988, Vol. 3, $3^{\text {rd }}$ Supplm.

6. Laubengayer, A. J.; Beachley, O. T.; Porter, R. F. Inorg. Chem. 1965, 4, 578

7. Schaeffer, G. W.; Schaeffer, R.; Schlesinger, H. J. Amer. Chem. Soc. 1951, 73, 1612

8. Riley, R. F.; Schack, C. J. Inorg. Chem. 1964, 3, 1651

9. Anton, K.; Nöth, H. Chem. Ber. 1981, 114, 2723

10. Anton, K. PhD Thesis, University of Munich, 1982.

11. O’Reilly, D. E. J. Chem. Phys. 1960, 32, 1007

12. Haraguchi, H.; Fujiwara, S. J. Phys. Chem. 1969, 73, 3467

13. Becher, H. J.; Frick, S. Z. Anorg. Allg. Chem. 1968, 295, 83

14. Cousen, D L.; Hoard, D. L. J. Amer. Chem. Soc. 1952, 74, 1742. Boese, R.; Maulitz, A. H.; Steilberg, P. Chem. Ber. 1994, 127, 1887. Jaska, C. A.; Temple, K.; Louch, A. J.; Manners, I. J. Amer. Chem. Soc. 2003, 125, 1424. Boese, R.; Blaser, D.; Steilberg, P.; Mauklitz, A. H. Z. Kristallogr. 1995, 210, 638

15. Lappert, M. F.; Srivastava, G. J. Chem. Soc. A 1967, 602

16. Harris, J. J. US Patent 1962, 3052 686; Chem. Abstr. 1963, 3402

17. Troll, A. PhD Thesis, University of Munich, 1999.

18. Dahl, C. H.; Schaffer, R. J. Amer. Chem. Soc. 1961, 83, 3032

19. Wiberg, E.; Hertwig, K. Z. Anorg. Allg. Chem. 1947, 255, 141

20. Dorion, C. E.; Green, F.; McMahon, T. B.; Vasudevan, K. Can. J. Chem. 1979, 57, 1751

21. Moehlen, M.; Neumüller, B.; Harms, K.; Krautscheid, H.; Fenske, D.; Diedenhofer, M.; Frenking, G.; Dehnicke, K. Z. Anorg. Allg. Chem. 1998, 624, 1105

22. Moehlen, M.; Neumüller, B.; Dehnicke, K. Z. Anorg. Allg. Chem. 1999, 625, 197 